Original Article

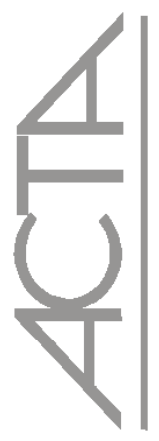

\title{
Risk factors for surgical site infection in cardiac surgery*
}

\author{
Fatores de risco para infecção de sítio cirúrgico em cirurgia cardíaca \\ Los factores de riesgo para la infecciones del sitio quirúrgico en s a cirugía cardíaca
}

Quenia Cristina Gonçalves da Silva ${ }^{1}$, Maria Helena Barbosa ${ }^{2}$

\begin{abstract}
Objective: To analyze the occurrence of surgical site infection (SSI) in patients undergoing cardiac surgery in the period between July 2005, and July 2010. Methods: A quantitative, historical cohort study that evaluated 384 patients in a public teaching hospital. The Statistical Package for the Social Sciences software was used for data analysis and for descriptive analysis, measures of association in contigency tables and logistic regression were used. Results: It was found that $36(9.4 \%)$ patients developed a SSI and that mortality occurred in 14 (38.9\%). Staphylococcus aureus was the prevalent microorganism $(12,27.3 \%)$ In the multivariate analysis, the risk factors identified as predictors of SSI were male gender, intubation for more than 24 hours, and reintubation. Conclusion: The risk factors predictive of the occurence of SSI ( $<<0.05)$ were: male gender, reintubation, and intubation for more than 24 hours.
\end{abstract}

Keywords: Surgical wound infection; Cardiac surgical procedures/adverse effects; Risk factors

\section{RESUMO}

Objetivo: Analisar a ocorrência de infecção de sítio cirúrgico (ISC) nos pacientes submetidos à cirurgia cardíaca no período ente julho de 2005 e julho de 2010. Métodos: Estudo de abordagem quantitativa, coorte histórica que avaliou 384 pacientes de um hospital público de ensino. Foi utilizado o software Statistical Package for the Social Sciences para a análise dos dados e para a análise descritiva, foram usadas medidas de associação em tabelas de contingência e regressão logística. Resultados: Verificou-se que $36(9,4 \%)$ pacientes evoluíram com ISC e que a mortalidade foi de $14(38,9 \%)$. O Staphylococcus aureus foi o micro-organismo prevalente 12 (27,3\%). Na análise multivariada, os fatores de risco identificados como preditores da ISC foram gênero masculino, tempo de intubação maior que 24 horas e reintubação. Conclusão: Os fatores de risco preditores para ocorrência de ISC $(\mathrm{p}<0,05)$ foram: gênero masculino, reintubação e tempo de intubação maior que 24 horas.

Descritores: Infecção de ferida operatória; Procedimentos cirúrgicos cardíacos/efeitos adversos; Fatores de risco

\section{RESUMEN}

Objetivo: Analizar la ocurrencia de infección de sitio quirúrgico (ISC) en pacientes sometidos a cirugía cardiaca en el período entre julio del 2005 y julio del 2010. Métodos: Estudio de abordaje cuantitativo, cohorte histórica en el que se evaluó a 384 pacientes de un hospital público de enseñanza. Fue utilizado el software Statistical Package for the Social Sciences para el análisis de los datos y para el análisis descriptivo, fueron usadas medidas de asociación en tablas de contingencia y regresión logística. Resultados: Se verificó que 36 (9,4\%) pacientes evolucionaron con ISC y que la mortalidad fue de 14 (38,9\%). El Staphylococcus aureus fue el microorganismo prevalente 12 (27,3\%). En el análisis multivariado, los factores de riesgo identificados como predictores de la ISC fueron género masculino, tiempo de intubación mayor de 24 horas y reintubación. Conclusión: Los factores de riesgo predictores para la ocurrencia de ISC $(\mathrm{p}<0,05)$ fueron: género masculino, reintubación y tiempo de intubación mayorior de 24 horas.

Descriptores: Infección de herida operatria; Procedimientos quirúrgicos cardíacos/efectos adversos; Factores de riesgo

\footnotetext{
* Article taken from Dissertation in Health Care, Federal University of Triangulo Mineiro (UFTM) entitled "Analysis of the occurrence of surgical site infection in patients undergoing cardiac surgery." Scholarship Capes/REUNI.

${ }^{1}$ Master degree in Health Care Program stricto sensu in Health Care, Federal University of Triângulo Mineiro - UFTM, Uberaba (MG), Brazil.

${ }^{2}$ PhD in Adult Health Nursing. Professor, School of Nursing, Federal University of Triangulo Mineiro - UFTM, Uberaba (MG), Brazil.
} 


\section{INTRODUCTION}

In Brazil, the surgical site infection (SSI) is a major infection related to health care; it is ranked as third among all infections in health services and comprises 14\% to $16 \%$ of infections found in hospitalized patients ${ }^{(1)}$.

The Centers for Disease Control and Prevention (CDC) has adopted the methodology of the National Nosocomial Infection Surveillance System (NNIS), developed criteria for defining the SSI. According to the CDC, the SSI occur in the first 30 days after surgery or up to one year in case of prosthesis. Therefore, the SSI are classified into superficial incision when involves skin and subcutaneous incision; deep incision when involves soft tissue such as fascia and/or muscle and organ/cavity (in cardiac surgery called mediastinitis), when involve any organ or cavity ${ }^{(2-4)}$.

In this context, the SSI in cardiac surgery is a complication of significant morbidity and mortality that increases costs of treatment ${ }^{(5,6)}$. The prolonged stay of patients with SSI represents an important economic factor, since they are spending almost triple the financial resources to patients with SSI than in those without infection, therefore it is clear that measures to prevent and control the SSI should be strengthened ${ }^{(5)}$.

The contamination of the surgical site can occur at any time during the perioperative period. Regarding transoperative period, in which there is exposure and manipulation of the tissue, during this period the entry of microorganisms is favored in the surgical site due to the existence of sources of infection, which may be endogenous (age, baseline disease) or exogenous (breaking aseptic barrier, inadequate hand hygiene) ${ }^{(7)}$.

According to literature, several factors may contribute to the occurrence of SSI, among them: diabetes mellitus (DM), obesity ${ }^{(8-10)}$, obstructive pulmonary disease $(\mathrm{OPD})^{(11-13)}$, age $\mathrm{e}^{(11.14)}$, female gender ${ }^{(8.15)}$, sternal reexploration for bleeding ${ }^{(10,16,17)}$, blood transfusion ${ }^{(17,18)}$, duration of preoperative hospitalization ${ }^{(4.14)}$, inadequate hand hygiene ${ }^{(4,7.19)}$, among others, as the use of prophylactic antibiotic at the right time ${ }^{(4.19)}$, clinical condition of the patient, prolonged surgery time and number of professionals in the operating room $^{(19)}$.

The identification of risk factors that contribute to the SSI occurrence, can provide information for planning and adoption of strategies in the prevention, control and monitoring of the infection in order to minimize their occurrence and maximize the principles of patient safety.

Although it has been observed in literature a low incidence of SSI in patients undergoing cardiac surgery, when it occurs, it is serious and may be fatal, which contributes to increased morbidity and mortality. Due to its clinical importance, this study is justified by the need to know the local reality to support the planning of care for this population in order to reduce the incidence of SSI and ensure better quality of care for patients.

It is noteworthy that in the hospital where the study was conducted, it was implemented in 2008, the Infection Control Protocol for Preventing Infection in Cardiac Surgery. However, the implementation of this protocol in clinical practice had a low adherence by professionals. This suggests a need for greater investment in education and training for these professionals, with views to the applicability of this recommendation to ensure quality of care and reduction of SSI for this population.

Considering the importance and scarcity of studies on the local reality related to this issue, this study aimed to determine the rate of SSI; identify potential risk factors and prevalent microorganisms; verify the association of SSI and length of hospital stay in the postoperative; verify the association of SSI and mortality among patients undergoing cardiac surgery in the Heart Surgery Unit of a large public hospital.

\section{METHODS}

Quantitative approach study, historical cohort, conducted in a public and teaching hospital, with 290 beds serving patients in high complexity of clinical and surgical specialties, located in the municipality of Uberaba (MG). The Heart Surgery Unit in this hospital has only one team that performs three heart surgeries weekly.

This research is part of the project, called "Occurrence of nosocomial infection in patients undergoing cardiac surgery," which was submitted to the Ethics Research Committee of the Federal University of Triangulo Mineiro and approved under No. 1611, subject to Resolution No. 196/96 on research involving human beings.

The study population consisted of all patients who underwent cardiac surgery between July 2005 and July 2010, who met the following inclusion criteria: aged from 18 years, having undergone cardiac surgery through longitudinal median sternotomy; have undergone coronary revascularization, valve repair or exchange, corrections of congenital defects, fixes of cardiac aneurysms; thoracic aorta and excision of cardiac tumors.

In the corresponding period, there were 589 cardiac surgeries, of these, 384 patients contemplated the inclusion criteria, constituting the study population.

Data were collected from medical records of all patients undergoing cardiac surgery and from reporting cards on nosocomial infection of patients diagnosed with SSI, provided by the Commission of Hospital Infection Control of the hospital. To guide those data, we used a data collection instrument that included the 
clinical and epidemiological factors related to risk factor for SSI occurrence.

In this study, the dependent variable was the presence of SSI and independent variables related to risk factors were: gender, age, underlying disease, smoking, body mass index (BMI), clinical condition, according to the American Society of Anesthesiologists (ASA), duration of preoperative hospitalization, previous infectious site, shaving, antiseptic for skin preparation, classification of surgery, type and duration of surgery, use and duration of cardiopulmonary bypass (CPB), blood transfusion, duration of intubation, reintubation and length of postoperative hospital stay.

Data were entered into an electronic spreadsheet in Excel ${ }^{\circledR}$ program for Windows ${ }^{\circledR}$ XP and validated by double entry. Data were exported and processed in the Statistical Package for the Social Sciences (SPSS) version 11.5 for Windows $\mathrm{XP}{ }^{\circledR}$ for processing and analysis.

Quantitative variables were analyzed as descriptive statistics, through measures of central tendency (mean and median) and variability (minimum, maximum and standard deviation - SD).

Data analysis to verify the existence of an association between SSI and categorical variables was performed using the chi-square $\left(\chi^{2}\right)$ test and we used the $t$ Student test to check the mean time between SSI and the length of hospital stay after surgery. The requirements for use of parametric tests such as normality and homogeneity of variance were analyzed using the Shapiro-Wilk test and Levene.

A bivariate analysis was done in order to explore the associations between the dependent variable (SSI) and the independent variables, whose associations were expressed by relative risk (RR), odds ratios (ORs) and their respective $95 \%$ confidence interval (CI).

In multivariate analysis, the associations were studied, based on logistic regression model, the dependent variable (SSI) with the independent variables whose association with SSI in bivariate analysis with $\mathrm{p} \leq 0.05$.

Results were considered significant at $5 \%(p<0.05)$, giving to these $95 \%$ of confidence that the results were correct.

\section{RESULTS}

In this study, from the 384 patients analyzed, 36 $(9.4 \%)$ were diagnosed with SSI.

In regard to sociodemographic characteristics, the majority were male $234(60.9 \%)$, and the mean age was 54.72 years (range 18-81 years). Regarding clinical aspects, in relation to comorbidities, 319 (83.1\%) patients had one or more baseline disease, and 264 $(48.6 \%)$ patients had hypertension (HBP). Among other features, $108(43.1 \%)$ were found with BMI $=25-29.9$

$\mathrm{kg} / \mathrm{m}^{2}$, which shows excess weight ${ }^{(20)}$ and $98(54.1 \%)$ patients were classified as ASA index P3 ie patient with severe systemic disease ${ }^{(21)}$. Regarding the surgical aspects, CABG surgery is highlighted performed in 187 (48.7\%) patients and the use of Polyvinyl Pyrrolidone Iodine (PPI), used in 158 (41.1\%), as an antiseptic of choice for skin preparation for surgery, as the data of Table 1 presents.

Table 1. Sociodemographic characteristics, clinical and surgical patients undergoing cardiac surgery. Uberaba-MG, 2005-2010.

\begin{tabular}{|c|c|c|c|}
\hline Variables & n $(\%)$ & Mean & SD \\
\hline \multicolumn{4}{|l|}{ Coming from } \\
\hline Uberaba & $252(65.6)$ & & \\
\hline Other places & $132(34.4)$ & & \\
\hline \multicolumn{4}{|l|}{ Gender } \\
\hline Male & $234(60.9)$ & 5472 & \\
\hline Female & $150(39.1)$ & $54 . / 2$ & 1.510 \\
\hline \multicolumn{4}{|l|}{ Age groups } \\
\hline $18-29$ years & $17(4.5)$ & & \\
\hline $30-39$ years & $35(9.1)$ & & \\
\hline $40-49$ years & $66(17.2)$ & & \\
\hline $50-59$ years & $118(30.7)$ & & \\
\hline $60-69$ years & $99(25.8)$ & & \\
\hline $70-79$ years & $47(12.2)$ & & \\
\hline$>80$ years & $2(0.5)$ & & \\
\hline \multicolumn{4}{|l|}{ Comorbidities } \\
\hline Hypertension & $264(48.6)$ & & \\
\hline Diabetes mellitus & $82(15.0)$ & & \\
\hline Chronic obstructive pulmonary disease & $35(6.4)$ & & \\
\hline Congestive heart failure & $34(6.2)$ & & \\
\hline Chronic renal failure & $15(2.7)$ & & \\
\hline Immunosuppressive disease & $4(0.7)$ & & \\
\hline Acute renal failure & $2(0.4)$ & & \\
\hline Other & $110(20.2)$ & & \\
\hline \multicolumn{4}{|l|}{ Smoking } \\
\hline No smoking & $124(32.3)$ & & \\
\hline smoking & $118(30.7)$ & & \\
\hline Used to smoke & $84(21.9)$ & & \\
\hline Not mentioned & $58(15.1)$ & & \\
\hline \multicolumn{4}{|l|}{ Body Mass Index (BMI)* } \\
\hline$<18,5$ & $7(1.8)$ & & \\
\hline $18,5-24,9$ & $94(24.5)$ & & \\
\hline $25-29,9$ & $108(28.1)$ & & \\
\hline $30-34,9$ & $27(7.0)$ & & \\
\hline $35-39,9$ & $10(2.6)$ & & \\
\hline$\geq 40$ & $1(0.3)$ & & \\
\hline Not mentioned & $137(35.7)$ & & \\
\hline Variables & n $(\%)$ & Mean & SD \\
\hline \multicolumn{4}{|l|}{ Clinical status (ASA score)** } \\
\hline P1 & $10(2.6)$ & & \\
\hline P2 & $69(18.0)$ & & \\
\hline P3 & $98(25.5)$ & & \\
\hline P4 & $4(1.0)$ & & \\
\hline Not mentioned & $203(52.9)$ & & \\
\hline
\end{tabular}




\begin{tabular}{|c|c|c|c|}
\hline Variables & n $(\%)$ & Mean & SD \\
\hline \multicolumn{4}{|l|}{ Previous Infection } \\
\hline Yes & $31(8.1)$ & & \\
\hline No & $353(91.9)$ & & \\
\hline $\begin{array}{l}\text { Hospitalization period (in days) } \\
\text { before surgery }\end{array}$ & & 7.07 & 7.701 \\
\hline \multicolumn{4}{|l|}{ Shaving } \\
\hline Yes & $234(60.9)$ & & \\
\hline No & $150(39.1)$ & & \\
\hline $\begin{array}{l}\text { Time of shaving performed before } \\
\text { surgery - in hours }\end{array}$ & & 6.09 & 1047.514 \\
\hline \multicolumn{4}{|l|}{ Antiseptic } \\
\hline Polyvinyl Pyrrolidone Iodine (PPI) & $158(41.2)$ & & \\
\hline $\begin{array}{l}\text { Association of PPI with other } \\
\text { antiseptics }\end{array}$ & $114(29.7)$ & & \\
\hline Chlorhexidine & $110(28.6)$ & & \\
\hline Alcohol iodized & $2(0.5)$ & & \\
\hline \multicolumn{4}{|l|}{ Surgery Classification } \\
\hline Elective & $381(99.2)$ & & \\
\hline Urgency & $3(0.8)$ & & \\
\hline \multicolumn{4}{|l|}{ Type of surgery } \\
\hline Coronary Revascularization (CR) & $187(48.7)$ & & \\
\hline Mitral valve exchange (MVE) & $67(17.4)$ & & \\
\hline Aortic valve exchange (AVE) & $58(15.1)$ & & \\
\hline Interatrial communications & $16(4.2)$ & & \\
\hline $\mathrm{MVE}+\mathrm{AVE}$ & $12(3.1)$ & & \\
\hline $\mathrm{AVE}+\mathrm{CR}$ & $9(2.3)$ & & \\
\hline Bentall & $5(1.3)$ & & \\
\hline $\mathrm{MVE}+\mathrm{CR}$ & $2(0.5)$ & & \\
\hline Interventricular communication & $1(0.3)$ & & \\
\hline Other & $27(7.0)$ & & \\
\hline Surgery duration - hours & & 3.755 & 1.0110 \\
\hline \multicolumn{4}{|l|}{ CPB } \\
\hline Yes & $374(97.4)$ & & \\
\hline No & $10(2.6)$ & & \\
\hline CPB time-minutes & & 75.70 & 32.280 \\
\hline \multicolumn{4}{|l|}{ Intraoperative blood transfusion } \\
\hline Yes & $52(13.5)$ & & \\
\hline No & $332(86.5)$ & & \\
\hline Duration of Intubation - hours & & 21.79 & 37.154 \\
\hline \multicolumn{4}{|l|}{ Reintubation } \\
\hline Yes & $29(7.6)$ & & \\
\hline No & $355(92.4)$ & & \\
\hline \multicolumn{4}{|l|}{ Postoperative blood transfusion } \\
\hline Yes & $206(53.6)$ & & \\
\hline No & $178(46.4)$ & & \\
\hline
\end{tabular}

* World Health Organization. ** American Society of Anesthesiologists

From 36 patients diagnosed with SSI, 14 types of microorganisms were identified with a prevalence of Staphylococcus aureus in $12(27.3 \%)$ patients, according to the data in Table 2.
Table 2. Distribution of microorganisms isolated from patients with SSI. Uberaba-MG, 2005-2010.

\begin{tabular}{ll}
\hline Isolated microorganisms & $\mathbf{n}(\mathbf{\%})$ \\
\hline Staphylococcus aureus & $12(27,3)$ \\
Klebsiela pneumoniae & $6(13,7)$ \\
Staphylococcus epidermidis & $4(9,1)$ \\
Escherichia coli & $4(9,1)$ \\
Staphylococcus coagulase negativa & $3(6,8)$ \\
Cedecea davisae & $3(6,8)$ \\
Enterobacter cloacae & $3(6,8)$ \\
Psendomonas aeruginosa & $2(4,5)$ \\
Acynetobacter baumanii & $2(4,5)$ \\
Enterobacter aerogenes & $1(2,3)$ \\
Corynebacterium spp. & $1(2,3)$ \\
Bastonetes gram-negativos & $1(2,3)$ \\
Morganela morganii & $1(2,3)$ \\
Acynetobacter calcoaceticus & $1(2,3)$ \\
\hline
\end{tabular}

Regarding antimicrobial therapy for the treatment of SSI, the most used antibiotic was Cefepime Hydrochloride $25(21.6 \%)$ Vancomycin 21 (18.1\%), Imipenem+ cilastatin sodium $17(14.7 \%)$ and Oxacillin sodium nine $(7.7 \%)$.

In relation to the length of ICU stay, mean length of stay of patients with SSI was 19.08 days (SD = 16.423), ranging from 4 to 70 days and patients without SSI, the mean was 4.95 ( $\mathrm{SD}=1.797)$, ranging from 2 to 15 days. As for the total time of hospitalization, mean length of stay of patients with SSI was 33.00 days (SD = 17.326), ranging from 6 to 76 days and patients without SSI mean was $8.24(\mathrm{SD}=3.051)$, ranging from 3 to 29 days.

In the bivariate analysis of the data, there was statistical significance $(\mathrm{p}<0.05)$ between gender and SSI $(\mathrm{RR}=2.2495 \%$ CI 1.07-5.44, $\mathrm{p}=0.030), \mathrm{HBP}(\mathrm{RR}$ $=2.82 \mathrm{CI} 95 \% 1.12-7.07, \mathrm{p}=0.018), \mathrm{DM}(\mathrm{RR}=2.63$ $95 \%$ CI 1.42-4.87, $\mathrm{p}=0.002), \mathrm{COPD}(\mathrm{RR}=3.8395 \%$ CI $2.02-7.28, \mathrm{p}<0.001)$, type of surgery $(\mathrm{RR}=2.64$ $95 \%$ CI 1.16- 6.00, $\mathrm{p}=0.015)$, duration of surgery $(\mathrm{RR}=2.5595 \%$ CI 1, 38- 4.73, $\mathrm{p}=0.002)$, duration of intubation ( $R R=3.9295 \%$ CI 2.14-7.19, $\mathrm{p}<0.001)$, reintubation $(\mathrm{RR}=6.9295 \%$ CI 3.93-12.17, $\mathrm{p}<0.001)$, duration of ICU stay (mean, 19.08 days, $\mathrm{p}<0.001$ ) and total hospitalization in postoperatively stay (mean 33 days, $\mathrm{p}<0.001)$.

In the multivariate analysis by logistic regression, it was found that there was statistical significance $(p$ $<0.05$ ) between SSI and gender, duration of intubation greater than 24 hours and reintubation, the reintubation variable showed the strongest association, as presented in Table 3. 
Table 3. Association between SSI and independent variables analyzed by logistic regression. Uberaba-MG, 2005-2010.

\begin{tabular}{|c|c|c|c|c|}
\hline \multirow[b]{2}{*}{ Independent Variables } & \multicolumn{2}{|c|}{ SSI } & \multirow{2}{*}{ *OR (CI) } & \multirow[b]{2}{*}{ p-value } \\
\hline & $\begin{array}{c}\text { YES } \\
\text { n (\%) }\end{array}$ & $\begin{array}{c}\text { NO } \\
\text { n (\%) }\end{array}$ & & \\
\hline \multicolumn{5}{|l|}{ Gender } \\
\hline Male & $28(12.0)$ & $206(88.0)$ & 3.65 & 0.029 \\
\hline Female & $8(5.3)$ & $142(94.7)$ & $(1.14-11.70)$ & \\
\hline \multicolumn{5}{|l|}{ Diabetes mellitus } \\
\hline Yes & $15(18.3)$ & $67(81.7)$ & 1.92 & 0.181 \\
\hline No & $21(7.0)$ & $281(93.0)$ & $(0.74-4.99)$ & \\
\hline \multicolumn{5}{|l|}{ Hypertension (HBP) } \\
\hline Yes & $31(11.7)$ & $233(88.3)$ & 3.83 & 0.081 \\
\hline No & $5(4.2)$ & $115(95.8)$ & $(0.85-17.39)$ & \\
\hline \multicolumn{5}{|l|}{ COPD } \\
\hline Yes & $10(28.6)$ & $25(71.4)$ & 2.86 & 0.092 \\
\hline No & $26(7.4)$ & $323(92.6)$ & $(0.81-9.73)$ & \\
\hline \multicolumn{5}{|l|}{ Type of Surgery } \\
\hline CABG & $23(11.6)$ & $175(88.4)$ & 0.72 & 0.581 \\
\hline Others & $7(4.4)$ & $152(95.6)$ & $(0.23-2.30)$ & \\
\hline \multicolumn{5}{|l|}{ Duration of Surgery } \\
\hline$>240$ minutes & $19(16.2)$ & $98(83.8)$ & 2.25 & 0.084 \\
\hline$<240$ minutes & $7(6.4)$ & $250(93.6)$ & $(0.90-5.64)$ & \\
\hline \multicolumn{5}{|l|}{ Duration of Intubation } \\
\hline$>24$ hours & $18(23.1)$ & $60(76.9)$ & 2.73 & 0.041 \\
\hline$<24$ hours & $18(5.9)$ & $288(94.1)$ & $(1.04-7.13)$ & \\
\hline \multicolumn{5}{|l|}{ Reintubation } \\
\hline Yes & $13(44.8)$ & $16(55.2)$ & 13.26 & $<0.001$ \\
\hline No & $23(6.5)$ & $332(93.5)$ & $(4.12-42.69)$ & \\
\hline
\end{tabular}

HBP: hypertension, COPD: chronic obstructive pulmonary disease, SSI: surgical site infection. * OR: Odds Ratio

Regarding the patients with SSI prognostic after cardiac surgery, it was found that from the 36 patients with SSI, $14(38.9 \%)$ died.

\section{DISCUSSION}

In this study, the incidence of SSI was higher than that identified in the literature, ranging between $0.2 \%$ and $5.6 \%{ }^{(8,10,16,22-25)}$. It is important to measure the rates of SSI, because they provide data that can lead to improvement of conditions observed and prevent this serious complication in patients undergoing cardiac surgery ${ }^{(5)}$.

Staphylococcus aureus was the prevalent microorganism, this result was corroborated by other studies ${ }^{(8,25)}$.

Regarding the mortality rate among patients with SSI, this research was $38.9 \%$, diverging from other studies in which the frequency ranged between $2.6 \%$ and $32.1 \%{ }^{(14,17,22-24)}$. Therefore, this result indicated that the diagnosis of SSI was constituted in an aggravation of the clinical condition of the patient, which may have favored the occurrence of complications with death.

In this study, we found that variables such as male gender, duration of intubation greater than 24 hours and reintubation were predictors of SSI in patients undergoing cardiac surgery ( $p<0.05$, multivariate analysis).

The prevalence of male gender was corroborated by other studies about patients who underwent cardiac surgery $(10,12,16,18,19,26,27)$. Regarding the higher incidence of SSI in male patients, this result is close to the findings of other studies ${ }^{(14,28,29)}$.

The mechanisms by which men are more prone to develop this type of infection compared to women are not yet known. One hypothesis suggests that men, because they have more hair follicles in the chest area where sternotomy is made, they may be more susceptible to bacterial growth and infection, but further studies are needed to elucidate this hypothesis ${ }^{(29)}$.

Although, in this study, reintubation has been identified as a high risk factor $(\mathrm{RR}=6.92)$ for developing SSI, there are few studies that address this issue (28). Therefore, the reasons for considering reintubation as a risk factor for SSI are still unclear, since the studies that analyzed risk factors for heart surgery, in most cases, did not mention this result, so more research is needed to address this aspect. However it can be thought that 
reintubation may be linked to the seriousness of patients with infection, since this status usually triggers multiple organic alterations in the patient. .

As for the duration of intubation, this study found that when this continue for more than 24 hours, it is considered a risk factor for SSI, and this result is confirmed by other studies ${ }^{(16,25,30)}$.

In this sense, it is understood that the longer the duration of intubation, the greater the patient's stay in the ICU will be, since they will be more exposed to environmental pathogens that their defense barriers may be compromised and also the multiplicity of procedures which are performed, all these features may facilitate the development of SSI.

Regarding the length of ICU stay, patients with SSI had a mean stay of 19.08 days, this result is supported by another study in which the mean ICU stay was 17.79 days ${ }^{(31)}$. As for the total time of hospitalization, the mean length of stay was 33 days, which differs from other studies that showed a mean time of stay between 40 to 56 days $^{(8,13,24,31,32)}$.

The prolonged hospitalization of patients with SSI represents an important economic factor, since the cost of treatment of patients with SSI is much higher than in those without infection because of the procedures such as dressings, laboratory tests, treatment, complications and use of antibiotics.

Considering the high costs of health services and the variety of options for the treatment of heart diseases, the identification of risk factors for patient's complications in postoperative may influence the decision about the appropriate course of action to be adopted for that patient ${ }^{(32)}$, with a view to prevention and control of SSI.

Among some important aspects concerning the prevention and control of SSI researched in this study, we highlight the skin antisepsis, time of performance of shaving before the surgical incision, identification of prior site infectious and comorbidities presence.

The choice of antiseptic solution should be based on knowledge of product efficacy, cost and ease of usage ${ }^{(33)}$. Although evidence points to the fact that chlorhexidine-based products for skin preparation for surgery have shown better results than other products for bacterial decolonization ${ }^{(34,35)}$, in this study, we observed low adherence of cardiac surgeons and health professionals who work in the surgical center to this product.

Shaving should be done only when necessary and must be done before surgery, at a time equal to or less than 2 hours ${ }^{(4)}$. This study showed that in most cases the mean time between the completion of shaving and the surgical incision was over 2 hours, which differs from the CDC recommendations ${ }^{(4)}$.

Despite having statistical significance between SSI and infection prior to surgery, the clinical relevance should be considered in this case. Therefore, identifying and treating existing infectious site before elective surgeries is a recommendation and their rescheduling should only be done after the resolution of the problem, ie, control of infectious site ${ }^{(4)}$.

Although some risk factors such as DM and COPD, are widely discussed in the literature as strong predictors for SSI ${ }^{(8-13)}$; in this study they were not associated with the occurrence of SSI. However, we must remember that prevention and control measures are essential and are directly related to the postoperatively prognosis (8, $, 17,22,25)^{\text {T Thus, }}$ health care programs that address to specific aspects of the person affected by these comorbidities should be implemented not only during hospitalization of patients, since many of postoperative complications may result from these decompensating cases associated with comorbidities.

It is noteworthy that this study has limitations such as the inability to evaluate aspects mainly related to the environment of the operating room, surgical scrub and incompleteness of secondary data, as noted in those related to smoking, record on weight and height to calculate BMI, ASA score, used as sources of information for this research. However, these limitations did not affect the achievement of the objectives proposed in this study, considering the study design adopted.

Thus, this research can inform the development of other prospective studies with a view to patient safety and quality of care, due to the importance of epidemiological surveillance of this infection, highlighting the need for reflection and discussion on the implementation of institutional protocols for promoting improved quality of care for this population.

\section{CONCLUSION}

This study has highlighted that the rate of SSI in patients undergoing cardiac surgery and the mortality rate were higher than shown in the literature and the most common microorganism was Staphylococcus aureus.

As predictors of SSI were also identified the variables: male, duration of intubation greater than 24 hours and reintubation. Regarding the length of ICU stay, the mean was 19.08 days and the total length of hospital stay, the mean was 33 days.

It is hoped that the results of this study may provide a basis for the elaboration of programs of prevention, control and monitoring, evidence-based, in order to reduce the incidence of SSI and ensure patient safety. 


\section{REFERENCES}

1. Brasil. Ministério da Saúde. Agência Nacional de Vigilância Sanitária. Sítio cirúrgico: critérios nacionais de infecções relacionadas à assistência à saúde. Brasília (DF): Ministério da Saúde; 2009.

2. Centers for Disease Control and Prevention. Procedureassociated events. Surgical Site Infection (SSI) Event [Internet]. 2010 [cited 2010 Set 8]. Available from: http:// www.cdc.gov/nhsn/PDFs/pscManual/9pscSSIcurrent.pdf

3. Horan TC; Gaynes RP. Critérios diagnósticos-NNIS. ANVISA, tradutor [Internet]. Brasilia (DF): ANVISA; 2005 [citado 2010 Set 20]. Disponível em: http://portal.anvisa.gov.br/wps/wcm/ connect/d83b9c8043391c99aae3aeff30613c2e/criterios_NNISS. pdf?MOD $=$ AJPERES\&useDefaultText $=0$ \&useDefaultDesc $=0$

4. Mangram AJ, Horan TC, Pearson ML, Silver LC, Jarvis WR. Guideline for prevention of surgical site infection, 1999. Hospital Infection Control Practices Advisory Committee. Infect Control Hosp Epidemiol. 1999; 20(4):247-78.

5. Graf K, Ott E, Vonberg RP, Kuehn C, Haverich A, Chaberny IF. Economic aspects of deep sternal wound infections. Eur J Cardiothorac Surg. 2010; 37(4):893-6.

6. Iyer A, Gilfillan I, Thakur S, Sharma S. Reduction of surgical site infection using a microbial sealant: a randomized trial. J Thorac Cardiovasc Surg. 2011; 142(2): 438-42.

7. Rebmann T, Kohut K. Preventing mediastinitis surgical site infections: executive summary of the Association for Professionals in Infection Control and Epidemiology's elimination guide. Am J Infect Control. 2011; 39(6):529-31.

8. Ahmed D, Cheema FH, Ahmed YI, Schaefle KJ, Azam SI, Sami SA, et al Incidence and predictors of infection in patients undergoing primary isolated coronary artery bypass grafting: a report from a tertiary care hospital in a developing country. J Cardiovasc Surg (Torino). 2011; 52 (1):99-104.

9. Al-Zaru IM, Ammouri AA, Al-Hassan MA, Amr AA. Risk factors for deep sternal wound infections after cardiac surgery in Jordan. J Clin Nurs. 2010; 19(13-14):1873-81.

10. Mannien J, Wille JC, Kloek JJ, van Benthem BH. Surveillance and epidemiology of surgical site infections after cardiothoracic surgery in The Netherlands, 2002-2007. J Thorac Cardiovasc Surg. 2011; 141(4):899-904.

11. Ariyaratnam P, Bland M, Loubani M. Risk factors and mortality associated with deep sternal wound infections following coronary bypass surgery with or without concomitant procedures in a UK population: a basis for a new risk model? Interact Cardiovasc Thorac Surg. 2010; 11(5):543-6.

12. Celik S, Kirbas A, Gurer O, Yildiz Y, Isik O. Sternal dehiscence in patients with moderate and severe chronic obstructive pulmonary disease undergoing cardiac surgery: the value of supportive thorax vests. J Thorac Cardiovasc Surg. 2011; 141(6): 1398-402.

13. Diez C, Koch D, Kuss O, Silber RE, Friedrich I, Boergermann J. Risk factors for mediastinitis after cardiac surgery - a retrospective analysis of 1700 patients. J Cardiothorac Surg. 2007; 2: 23.

14. Filsoufi F, Castillo JG, Rahmanian PB, Broumand SR, Silvay $G$, Carpentier A, et al Epidemiology of deep sternal wound infection in cardiac surgery. J Cardiothoracic Vasc Anesth. 2009; 23(4):488-94.

15. Trussel J, Gerkin R, Coates B, Brandenberger J, Tibi P, Keuth $\mathrm{J}$, et al. Impact of a patient care pathway protocol on surgical site infection rates in cardiothoracic surgery patients. Am J Surg. 2008; 196(6):883-9.

16. Baillot R, Cloutier D, Montalin L, Côté L, Lellouche F, Houde C, et al. Impact of deep sternal wound infection management with vacuum-assisted closure therapy followed by sternal osteosynthesis: a 15-year review of 23,499 sternotomies. Eur J Cardiothorac Surg. 2010; 37(4):880-7.
17. Magedanz EH, Bodanese LC, Guaragna JC, Albuquerque LC, Martins V, Minossi SD, et al. Risk score elaboration for mediastinitis after coronary artery bypass grafting. Rev Bras Cir Cardiovasc. 2010; 25(2):154-9.

18. Mohnle P, Snyder-Ramos SA, Miao Y, Kulier A, Böttiger BW, Levin J, et al. Postoperative red blood cell transfusion and morbid outcome in uncomplicated cardiac surgery patients. Intensive Care Med. 2010; 37(1):97-109.

19. Tartari E, Mamo J. Pre-educational intervention survey of healthcare practitioners' compliance with infection prevention measures in cardiothoracic surgery: low compliance but internationally comparable surgical site infection rate. J Hosp Infect. 2011; 77(4):348-51.

20. Obesity: preventing and managing the global epidemic. Report of a WHO Consultation. World Health Organ Tech Rep Ser. 2000; 894:i-xii, 1-253.

21. American Society of Anesthesiologists. ASA Physical Status Classification System [Internet] [cited 2010 Mar 17]. Available from: http://www.asahq.org/clinical/physicalstatus.htm

22. López Gude MJ, San Juan R, Aguado JM, Maroto L, LópezMedrano F, Cortina Romero JM, Rufilanchas JJ. Case-control study of risk factors for mediastinitis after cardiovascular surgery. Infect Control Hosp Epidemiol. 2006; 27(12):1397-400.

23. Ngaage DL, Cale AR, Griffin S, Guvendik L, Cowen ME. Is post-sternotomy percutaneous dilatational tracheostomy a predictor for sternal wound infections? Eur J Cardiothorac Surg. 2008; 33(6):1076-9; discussion 1080-1.

24. Sá MP, Figueira ES, Santos CA, Figueiredo OJ, Lima RO, Rueda FG, et al. Validation of MagedanzSCORE as a predictor of mediastinitis after coronary artery bypass graft surgery. Rev Bras Cir Cardiovasc. 2011; 26(3):386-92.

25. Sachithanandan A, Nanjaiah P, Nightingale P, Wilson IC, GrahamTR, Rooney SJ, et al. Deep sternal wound infection requiring revision surgery: impact on mid-term survival following cardiac surgery. Eur J Cardiothorac Surg. 2008; 33(4):673-8.

26. Andrade EV, Barbosa MH, Barichello E. Pain assessment in postoperative cardiac surgery. Acta Paul Enferm. 2010; 23(2):224-9.

27. Dantas RA, Rossi LA, Costa MC, Vila VS. [Quality of life after myocardial revascularization: evaluation according to two methodological perspectives]. Acta Paul Enferm. 2010; 23(2):163-8. Portuguese.

28. Ennker IC, Malkoc A, Pietrowski D, Vogt PM, Ennker J, Albert A. The concept of negative pressure wound therapy (NPW'T) after poststernotomy mediastinitis - a single center experience with 54 patients. J Cardiothorac Surg. 2009; 4:5.

29. Risnes I, Abdelnoor M, Almdahl SM, Svennevig JL. Mediastinitis after coronary artery bypass grafting risk factors and long-term survival. Ann Thorac Surg. 2010; 89(5):1502-9.

30. Lucet JC; Parisian Mediastinitis Study Group.Surgical site infection after cardiac surgery: a simplified surveillance method. Infect Control Hosp Epidemiol. 2006; 27(12):1393-6.

31. Sá MP, Soares EF, Santos CA, Figueiredo OJ, Lima RO, Escobar $\mathrm{RR}$, et al. Risk factors for mediastinitis after coronary artery bypass grafting surgery. Rev Bras Cir Cardiovasc. 2011; 26(1):27-35.

32. Strabelli TM, Stolf NA, Uip DE. Practical use of a risk assessment model for complications after cardiac surgery. Arq Bras Cardiol. 2008; 91(5):342-7.

33. Hemani ML, Lepor H. Skin preparation for the prevention of surgical site infection: which agent is best? Rev Urol. 2009; 11(4):190-5.

34. Alexander JW, Solomkin JS, Edwards MJ. Updated recommendations for control of surgical site infections. Ann Surg. 2011; 253(6): 1082-93.

35. Darouiche RO, Wall MJ Jr, Itani KM, Otterson MF, Webb AL, Carrik MM, et al. Chlorhexidine-alcohol versus povidone-iodine for surgical-site antisepsis. N Engl J Med. 2010; 362(1):18-26. 